\title{
光活性化アデニル酸シクラーゼ合成酵素OaPACの 活性化機構解明
}

\author{
横浜市立大学大学院生命医科学研究科構造創薬科学研究室 大木規央, 朴 三用
}

\section{Mio OHKI and Sam-Yong PARK: Structural and Functional Insights into a Photoactivated Adenylyl Cyclase}

Cyclic-AMP is one of the most important second messengers, regulating many crucial cellular events in both prokaryotes and eukaryotes. Precise spatial and temporal control of cAMP levels by light shows great promise as a simple means of manipulating and studying numerous cell pathways and processes. The photoactivated adenylate cyclase (PAC) from the photosynthetic cyanobacterium Oscillatoria acuminata is a small homodimer eminently suitable for this task, requiring only a simple flavin as chromophore. Here we describe its structure using X-ray crystallography and crystal microspectrophotometry. Site-directed mutants show signal transduction over 30 Ångstroms across the protein with minimal conformational rearrangement. The use of the protein in living human cells is demonstrated with cAMP-dependent luciferase, showing a rapid and stable response to light over many hours and activation cycles.

\section{1. はじめに}

フラビンを発色団としてもつ新規の青色光受容体夕 ンパク質が, 紅色光合成細菌より発見された。この光受 容体のフラビン結合ドメインは, 原核および真核微生物 に幅広く保存されていることがわかり, それらは光応答 に関与する光受容体と考えられている。原生動物である ミドリムシ (Euglena gracilis) にも光逃避反応の光セン サー分子が発見され, その分子は光活性化アデニル酸シ クラーゼ (PAC ; Photoactivated Adenylyl Cyclase) である ことが見出された. ${ }^{1)} \mathrm{PAC}$ 分子は動物・植物で普遍的な 情報伝達物質 (cAMP) の生産を光で制御できる生体夕
ンパク質であり, 生体内での光スイッチとして医学的な 応用が期待される分子である. また, 哺乳類の脳分化に おいて, 青色光照射による制御 (オプトジェネティクス, Optogenetics）など, 生体内での光スイッチとして医学的 な応用が期待される分子である. 光活性化アデニル酸シ クラーゼは最初にミドリムシの光忌避センサーとして発 見され ${ }^{2)}$ 以後, シアノバクテリア (Oscillatoria acuminata) 由来の PAC ( OaPAC) など, 複数の微生物からも相同遺 伝子が見出されていたが,3)-5) いずれも原子レベルでの 構造・機能解明までには至っていない. OaPACはミド リムシのPACより小さい分子からなり, 同様の分子機能 をもっている(図1). OaPACは366アミノ酸残基からな

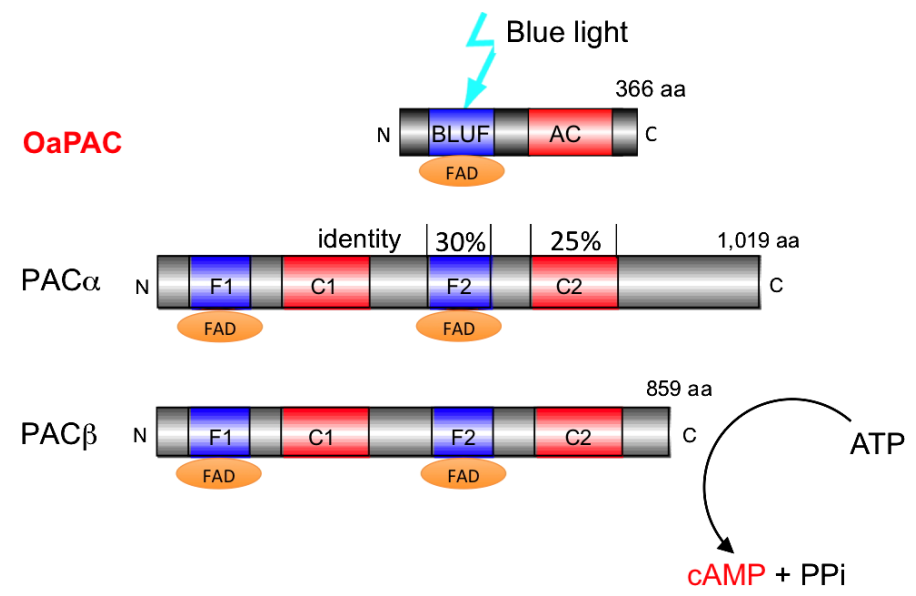

図1 PACドメインの配列とアミノ酸の相同性. (Sequence homolog in the PAC family.) ミドリムシ (Euglena gracilis) と OaPACのドメイン構造を示す。ミドリムシのPAC $\alpha$ と-サブユニットでは, それぞれ2つのBLUFドメイン（F） と $\mathrm{AC}$ ドメイン $(\mathrm{A})$ をも, $\mathrm{OaPAC}$ の各アミノ酸の相同性を示す. 
り，フラビン色素 (FAD) を結合する光センシングドメ インとATPを cAMPに変換する触媒ドメインおよびその 両者をつなぐリンカー領域をもつ(図1).このフラビン 結合ドメインは, クリプトクロム（Cryptochrome）また はフォトトロピン (Phototropin) のものとは一次構造に おける相同性が異なることから, 新規の青色光受容機能 を有すると考えられ, BLUF (sensors of Blue-Light Using FAD）と名付けられた.6) 本稿では, OaPAC光活性化アデ ニル酸シクラーゼの原子レベルでの解析から, 光活性化 メカニズムに関する最新の知見を紹介したい.7

\section{2. シアノバクテリア由来の光活性化アデニル酸シ クラーゼ OaPAC}

\subsection{OaPACの発現, 精製, 結晶化}

シアノバクテリア由来 OaPAC (1-366残基) の遺伝子 を, N末端の領域にHis タグと FactorXaサイトが付加さ れたpCold Iベクターに挿入した. 作製したプラスミド を用いて E. coli ArcticExpress株に形質転換し, 培養, 精 製を行い, $1 \mathrm{~L}$ 培地当たり, 約 $3 \mathrm{mg}$ の高純度なサンプル を得た。結晶化スクリーニングキットにより, OaPACの 結晶化条件を探索し, 最終的に $100 \mathrm{mM}$ クエン酸ナトリ ウム $\mathrm{pH}=5.0,10 \% \mathrm{PEG} 20 \mathrm{~K} に よ り$, 微結晶を得ること ができた。しかし, 構造解析に用いられる単結晶ではな く, さらに良好な結晶を得るために, 結晶化用添加剤キッ 卜 (Additive Screen Kit) を用いて結晶化条件の最適化 を行った。 その結果, 最終的に $10 \mathrm{mM}$ マロン酸ナトリ ウム $\mathrm{pH}=7.0,100 \mathrm{mM}$ クン酸ナトリウム $\mathrm{pH}=5.0$, $10 \%$ PEG20Kをリザーバー溶液として用い, 結晶化温 度 $20{ }^{\circ} \mathrm{C}$ にて, 大きさ約 $30 \times 50 \times 100 \mu \mathrm{m}$ の結晶を得る ことができた。結晶の空間群は $P 2{ }_{1} 2{ }_{1} 2_{1}, a=83.76 \AA, b$ $=99.78 \AA, c=122.87 \AA$ であり, 分解能 $3.1 \AA$, 結晶学 的な非対称単位 $\left(V_{M}=3.15 \AA^{3} / \mathrm{Da}\right.$, 溶媒率 $\left.=61 \%\right)$ 当た り 2 分子が存在することが確認された. OaPAC構造は 類似の構造が存在せず, 得られた結晶の位相問題を解 決するため,さまざまな重原子同型置換結晶を作製し た. 最終的に $10 \mathrm{mM-EMTS} \mathrm{(ethylmercurithiosalicylate,}$ Thimerosal), 24 時間ソーキングを行った結晶を用いて, 分解能 $3.3 \AA$ の良好なデー夕を収集することができ, 位 相の決定をすることができた. ATP 非存在下の条件で得 られたClosed 状態の結晶に関しては, 最終的に分解能 $2.9 \AA$ で解析することができた。 また, 同条件にて結晶 化を行った結果, $5 \mathrm{mM}$ ATP-analog $(\alpha, \beta$-methylene ATP : ApCpp), $2 \mathrm{mM} \mathrm{MgCl}$ を添加することにより, Open状 態の結晶を得ることができた. Open状態の結晶は分解 能 $1.8 \AA$, 空間群 $P 6_{1} 22$ に属し, 非対称単位中に 1 分子の OaPACが存在した。

\section{$2.2 \mathrm{OaPAC}$ 全体構造}

OaPAC は, フラビン結合部位である BLUFドメイン

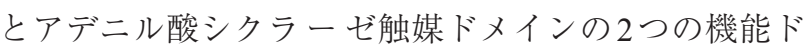
メインからなる. BLUFドメインを有するタンパク質は $450 \mathrm{~nm}$ 付近にフラビンに由来する吸収極大をもち, 光 照射に伴い吸収スペクトルが数 $\mathrm{nm}$ 長波長側にシフトす ることが知られている。度,9) 大腸菌に発現させて単離精 製したOaPACはフラビンモノヌクレオチド（FMN）を 保有しており, ラピッドスキャン分光測定により, 光照 射時のFMNの吸収変化を見ると, 図2に示したように $442 \mathrm{~nm}$ から $445 \mathrm{~nm}$ にレッドシフトを示し, 光照射終了 後約 20 秒程度で完全に緩和される.この反応のキネティ クスはLight状態から Dark状態への 2 成分の反応を示唆 する。点線の表示はLight と Darkの差スペクトルを表す (図2a).

われわれはOAPACについて結晶化条件を変えること により2種類の異なる結晶を得ることができ, それらの 構造解析を行った (図2a). OaPACの全体構造は, 12 本 の $\alpha$ ヘリックスと 13 本の $\beta$ シートからなっている. $\mathrm{N}$ 末 端にはフラビンを結合したBLUFドメインとC末端側に はアデニル酸シクラーゼ触媒 (AC) ドメインからなり, ダンベル型となっている（図 $2 \mathrm{~b}$ ). また, それぞれのド メイン同士は隣り合わせになっていることが明らかと なった. BLUFの保有するフラビン分子とアデニル酸シ クラーゼの活性部位との距離は約 $48 \AA$ と離れているこ とが確認された。

さらに，異なる結晶化条件に基質ATPのアナログ $\mathrm{ApCpp}$ 分子の有無により $\mathrm{AC}$ に゙メインが開いた状態 (Open) になっている構造 (空間群 $P 2{ }_{1} 2_{1} 2_{1}$ ) と閉じた状態 (Closed) になっている構造 (空間群P6122) がそれぞれ存 在することがわかった. OaPACのOpen状態とClosed状 態の各ドメイン構造を比較すると, BLUFドメインでは

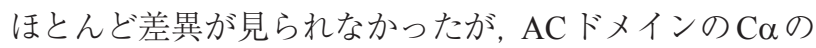
変化が約 $2 \AA$ ほど開いている，また，分子間でのファンデ ルワールスコンタクトの面積はOpen状態では 3,660 $\AA^{2}$, Closed状態では 4,020 $\AA^{2}$ となっており, BLUFドメインの ファンデルワールスコンタクト面積は変化せず, $\mathrm{AC}$ ド メインが変化し，開閉していることが明らかになった。

\subsection{BLUFドメイン}

OaPACのBLUF ドメインは，ほかのBLUF ドメインタン パク質 ${ }^{10), 11)}$ と同様に2本の $\alpha$ ヘリックスと 5 本の $\beta$ シー トからなる典型的な BLUF構造になっているが, 既知の BLUFドメインは単量体であるのに対し, OaPACは二量 体を形成している（図3a）。われわれは，変異導入によ り BLUFドメインを欠失させたOaPACを作製し，超遠心 分析 (Analytical Ultracentrifugation) でACドメインの安 定性を測定した結果, 不安定で二量体を形成しなくなっ ていた。つまり, OaPACのBLUFドメインが二量体を形 成することで, ACドメインの安定化につながる重要な 役割をしていることが明らかになった。また，OaPACの 

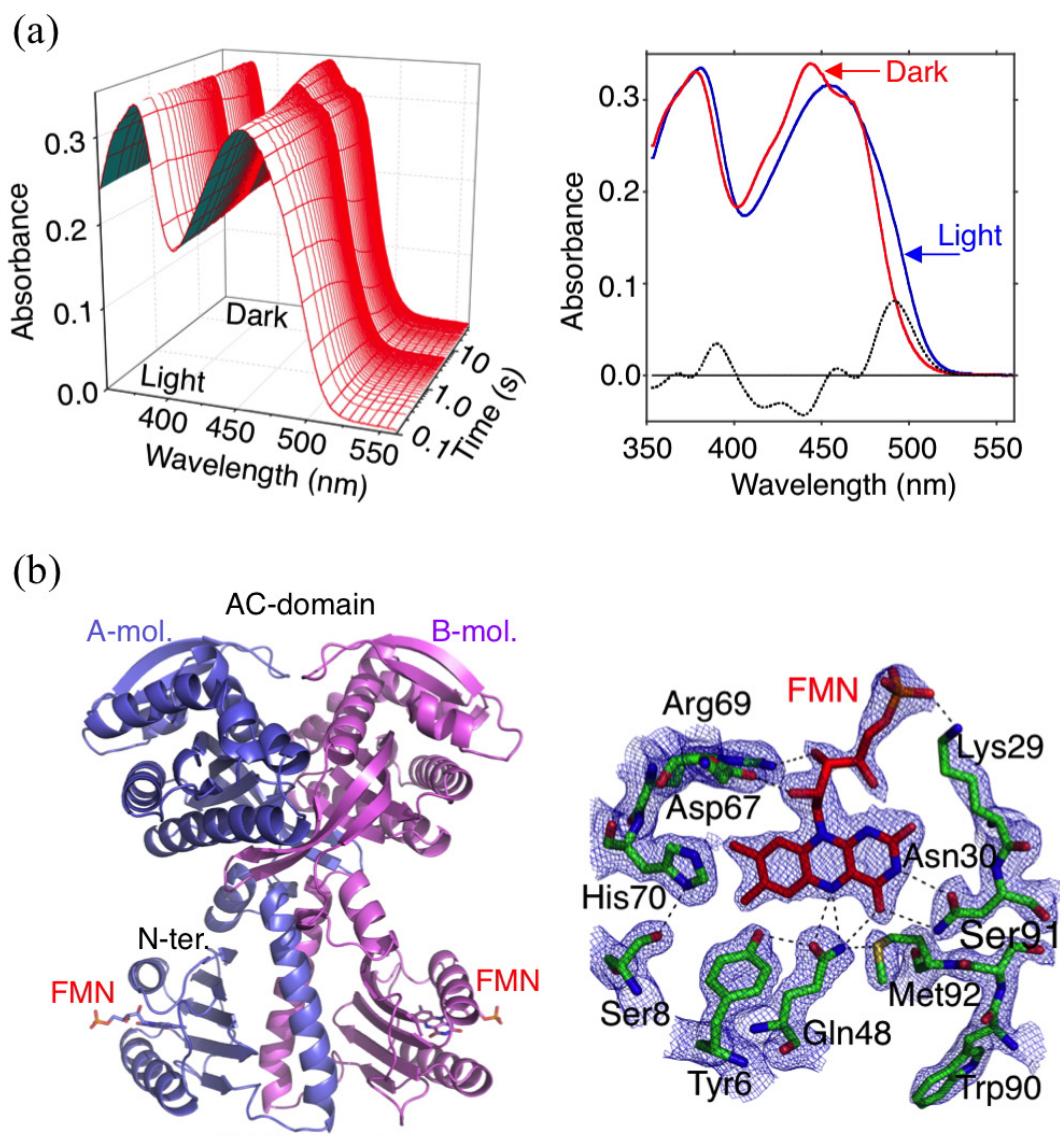

BLUF-domain

図2 OaPACタンパク質の吸収スペクトルと立体構造. (Overall structural properties and solution absorption spectra of OaPAC.) (a) OaPAC タンパク質のラピッドスキャン分光測定により, FMNの吸収変化を Lightから Darkへの吸 収スペクトルである. 強力スポット光源の白色光を 5 秒照射した後に 100 ミリ秒から 52 秒までの吸収スペクト ルを 100 ミリ秒時間分解能で測定し, $442 \mathrm{~nm}$ から $445 \mathrm{~nm}$ にレッドシフト示す. 点線の表示はLight と Darkの差 スペクトルを表す。（b）OaPACの全体構造で, OaPACの全体構造は, 12本の $\alpha$ ヘリックスと 13 本の $\beta$ シートか らなっている. N末端にはフラビン結合BLUFドメインとC末端側にはアデニル酸シクラーゼ (AC) ドメイン から合成され, ダンベル型の二量体からなっている。 フラビン (FMN) C5 原子から, Gln48 と水素結合が見ら れており, Dark状態の構造である. 編集部注：カラーの図は電子版を参照下さい.

BLUFドメイン二量体と既知のBLUF構造（TII0078，黄 色で表示) とを重ね合わせて見ると, OaPACの $\alpha 3$ アリッ クスは非常に長く, そのC末端は上部の $\mathrm{AC}$ ドメインに

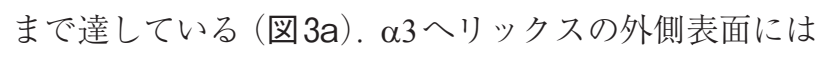
疎水性残基が集中し, その疎水性相互作用により二量体 が形成されていた。これは既存のBLUFドメインの構造 には見られない, 唯一OaPACのみに特徵的な構造であ る.ささらに, 構造が未知のPACファミリーのアミノ酸一 次配列を比較すると, OaPAC構造の $\alpha 3$ 3リックスと思 われるアミノ酸はそれぞれ保存されており，また両親媒 性ヘリックスを描くと, PACファミリーに扔いて疎水性 アミノ酸は二量体を形成する接触面のみに集中してい る. PACファミリーの構造は $\alpha 3$ ヘリックスが各分子同 士をささえ, 二量体を形成して活性機能を有していると 考えられる。

\subsection{ACドメイン}

OaPACのAC ドメインは 8 本の $\alpha$ ヘリックスと7本の $\beta$ シートからなっており, 構造既知のアデニル酸シクラー
ゼ $(\mathrm{CyaC})^{12)}$ の $\mathrm{AC}$ ドメインとほぼ一致している。しかし, 今回の構造では金属イオン $\left(\mathrm{Mg}^{2+}\right), \mathrm{ApCpp}$ 分子を加えて 結晶化させているにもかかわらず, 構造から電子マップ を特定するには至らなかった，また，OaPACの溶液状態 で, 等温滴定型熱量測定 (Isothermal Titration Calorimetry； ITC）によるATP分子の結合も見られなかった.

ACドメインの構造では基質 ATP 結合部位と思われる 広い領域が存在しており, 酵素反応に重要な金属結合に かかわるアミノ酸残基Asp156, Asp200 も存在し, cAMP 生成反応にかかわっていることが確認された、構造既知 のCyaCはBLUFドメインがなく, ACドメインのみもつ 酵素でOaPACの基質結合部位を比較すると同じアミノ 酸からなっている. また, $\mathrm{CyaC}$ 分子は二量体で活性機能 を有していることが知られており, OaPAC分子も溶液中 に执いては超遠心分析やゲルろ過の結果から二量体を形 成しているということが確認され, 結晶と溶液の分子状 態がよく一致していた. CyaC分子は二量体で安定な夕 ンパク質として活性を示すが, OaPACではBLUFドメイ 
(a)

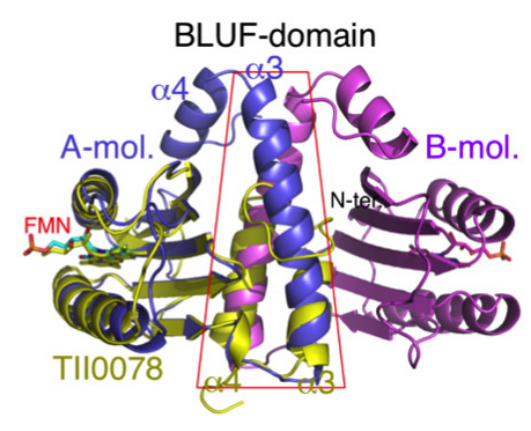

(c)

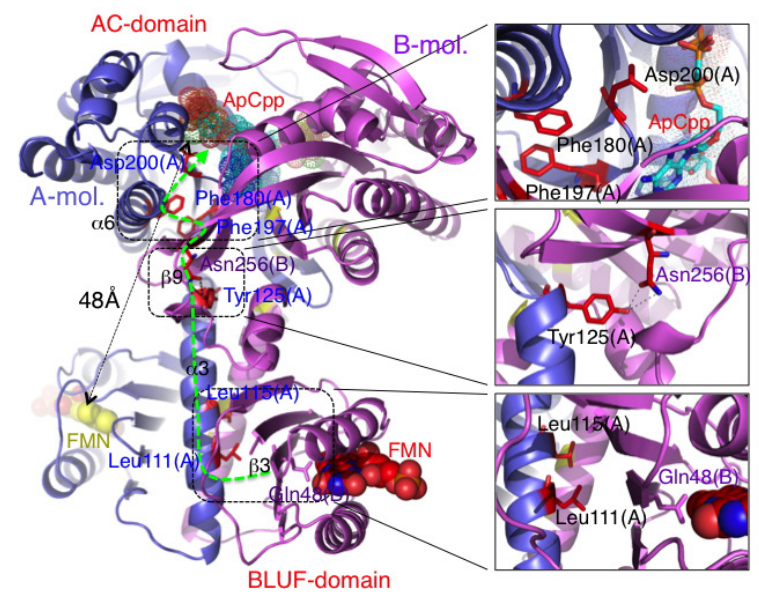

(b)

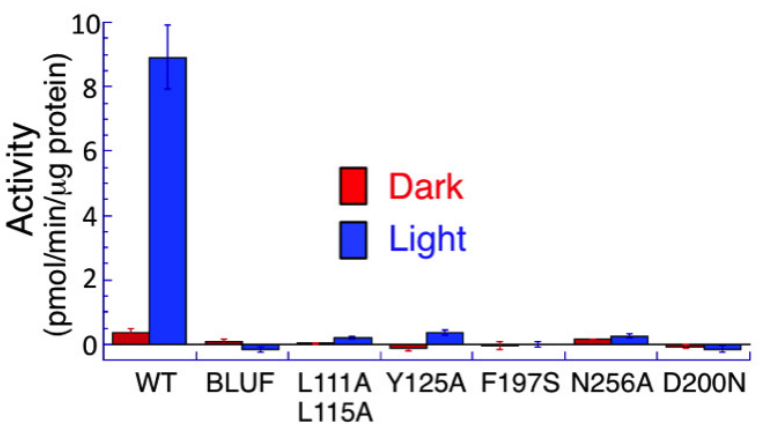

(d)

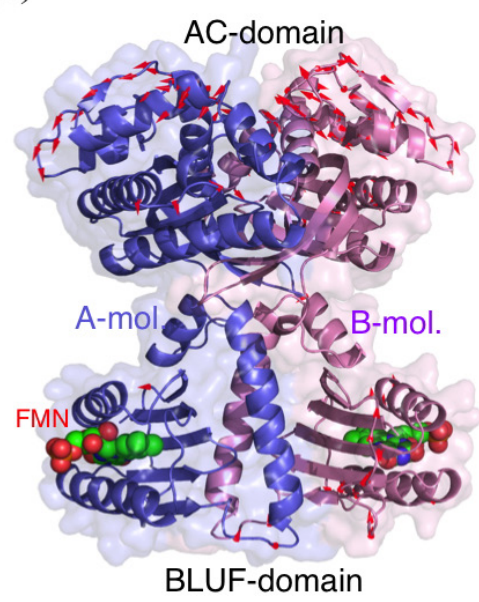

図3 OaPAC タンパク質変異体の活性測定と活性機構. (Enzyme assays and proposed photo-activated regulation pathway of OaPAC.) (a) OaPAC タンパク質の構造から BLUFドメイン二量体と既知のBLUF構造（TII0078，黄色で表 示）とを重ね合わせて見ると, OaPACの 23 ヘリックスは非常に長く, 二量体の構造になっている. (b) 変異体 による cAMPの活性測定. (c) OaPACタンパク質と結合している FMN と水素結合をしている Gln48 の背部にあ る 23 ヘリックスのLeu111/Leu115, さらにTyr125, Asn256, Phe197, Asp200のそれぞれの変異体の部分と, 黄 色い点線の矢印で活性機構経路を示している. (d) OaPACの Open 状態とClosed状態の構造をC $\alpha$ 重㸚合わせ, $1.5 \AA$ 以上変化しているアミノ酸残基を赤色矢印で表した. BLUFドメインではほとんど差異が見られなかっ

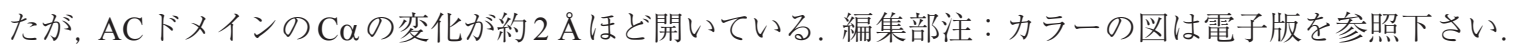

ンが二量体を形成することで, ACドメインが安定な二 量体となり活性を示す.これはPACファミリーの特徵的 な構造であると考えられる。

\section{OaPACの変異体による機構解明}

OaPAC立体構造の情報から, PACの光刺激によるアデ ニル酸シクラーゼの活性機構を解明するために変異体 を作製し, 機能解析を行った. フラビン分子と水素結合 をしている $\mathrm{G} \ln 48$ の背部にある $\alpha 3$ ヘリックスの Leu111/ Leu115 (二重置換体), さらにTyr125, Asn256, Phe197, Asp200のそれぞれの変異体によるcAMP活性測定を 行った. 野生型OaPAC と比べ青色光の有無では著しく 活性低下が見られた（図3b). OaPAC変異体の活性結果 を踏まえて, 光による cAMP合成に重要なアミノ酸残基 を特定することができ, OaPAC構造からアデニル酸シ クラーゼ活性の光刺激による活性機構経路を推測した

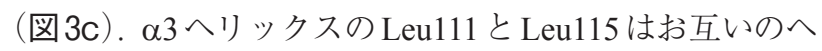

リックスが疎水性相互作用により安定化するのに重要な 役割を担っていると考えられる。 また, Tyr125とAsn256 はそれぞれの側鎖を介してサブユニット間の水素結合 を共有していることがわかり, ACドメインに存在して いるPhe197とPhe180は $\pi-\pi$ 結合を形成しており, 活性 部位の構造安定化に重要な役割を担っていると考えら れる.さらに,Asp200はアデニル酸シクラーゼの活性サ イトに扮いて触媒となる金属イオン配位結合を形成す るために重要なアミノ酸であることも明らかとなった。 その光刺激による構造変化は黄色い点線の矢印で示し たような活性機構経路となると推測できる（図3c）.

また, BLUFドメインとACドメインの距離は約 $48 \AA$ も離れている。 これは，抒そらく光励起されたフラビン 分子によるBLUFドメインの微細な構造変化が分子間の アロステリックコンフォメーションを引き起こし, AC ドメインが開閉されることにより cAMP合成反応の活性 化が起こっていると考えられる (図3d). 


\section{4. 光遺伝学への展開}

\section{1 細胞への応用}

OaPAC は光によって cAMP生成を制御できる利点か ら, 光遺伝学 (オプトジェネティクス)1),13) などへの応 用が期待される.また, 既存の光遺伝学ツールとして報 告されている光依存性のイオンチャネルやイオンポンプ とは異なる分子機能の制御ができるメリットも有する夕 ンパク質である.

われわれはOAPACをHEK293細胞に発現させ，青色 光照射により細胞内の cAMPレベルを制御することを 試みた（図 4a）。実験ではpGloSensor-22Fベクターを用
いて, OaPAC 遺伝子とホタルイカのルシフェラーゼ遺 伝子を共発現させ, cAMP検出プローブである Glosensor cAMP Assayによりルシフェラーゼの発光を検出するこ とでcAMPを定量し, 細胞内cAMPをリアルタイムに可 視化・定量化を行った。 その結果, OaPAC発現細胞内の cAMP濃度は, 光刺激により一過的に上昇し, その後, 数分以内に分解されることがわかった (図4a). また, 刺 激光の強度とパルス間隔の調節により, 細胞内 cAMP濃 度を 8 時間以上高いレベルに保持できることも確認し, OaPACの光操作ツールとしての実効性を示した。

また, 既知のPACホモログであるbPACと OaPACとの HEK細胞内における活性強度の比較定量化を行った。

\section{(a)}
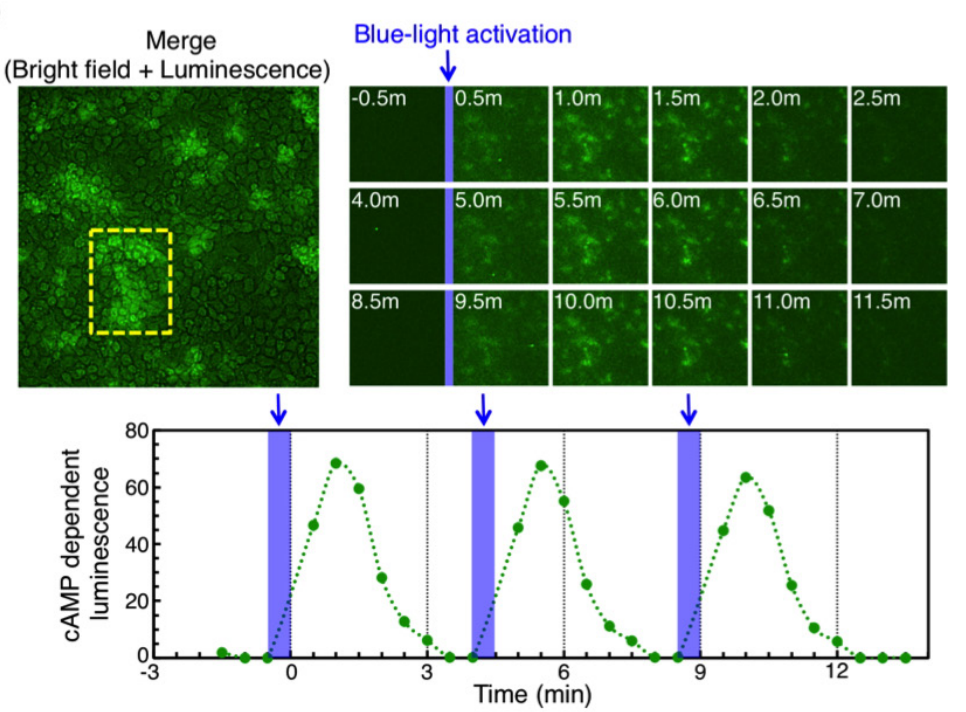

(b)
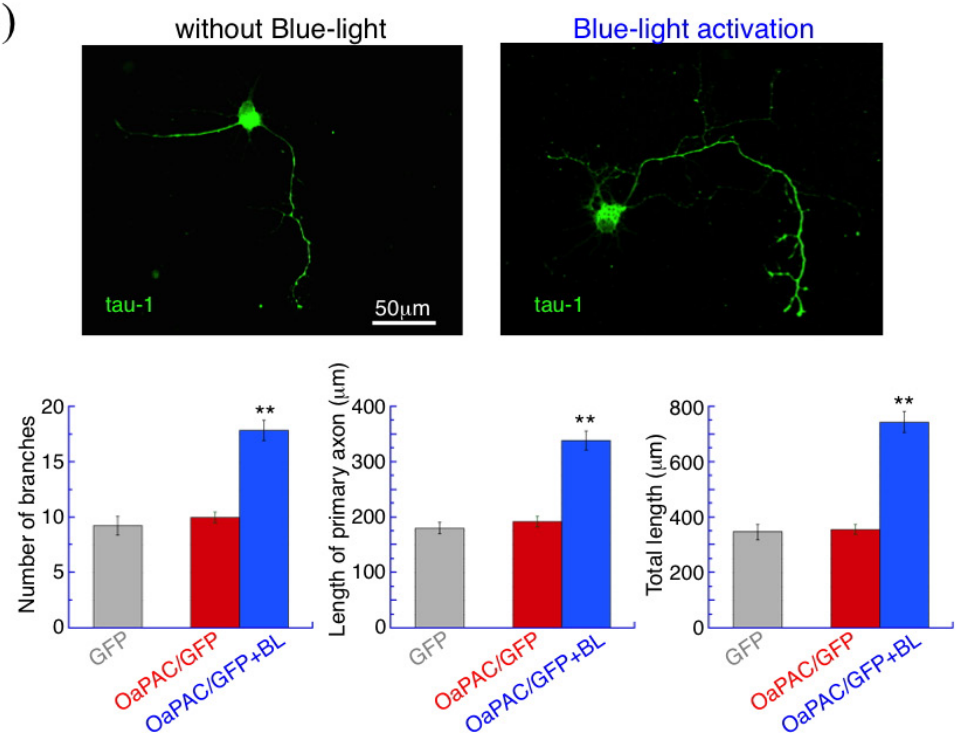

図4 OaPAC タンパク質の光遺伝学への応用. (Use of OaPAC to generate cAMP in cultured cells for optogenetics.) (a) OaPAC 分子をHEK293 細胞に発現させ, 青色光照射により細胞内のcAMPの制御を行った. 細胞に 3 分ごとに 30 秒光を照射し, 細胞内での cAMPをリアルタイムに可視化・定量化を行った. (b) OaPAC分子をマウスの海 馬の神経細胞に発現させ, 神経細胞の軸索の分岐・伸長の光操作を試みた. 細胞培養の 4 日目に青色光を 30 分 照射し，7日目に観察すると，光照射のあるなしで軸索の長さに違いが見られた，軸索の分岐においても差異 が見られ，青色光を照射した細胞のほう（青色）が照射なし（赤色）より，神経軸索の分枝数が増加している. 編集部注：カラーの図は電子版を参照下さい. 
その結果, 両者の活性量はおよそ 100 倍の差があること が明らかになり, cAMPの広範囲な応用が期待され, 有 用な遺伝子資源になると考えられる。

\section{2 神経細胞の制御}

光遺伝学的手法において, 神経細胞の構造形成や神経 回路形成のメカニズムを解明するためには，イオンチャ ネルだけでなく, 細胞内シグナル伝達系を時空間的に制 御する方法が必要となる。また, 近年では神経軸索の分 岐・伸長の誘導には cAMPの介在が必須であると報告さ れている.14),15) そこでわれわれはOaPACをマウスの海 馬の神経細胞に発現させ, 神経細胞の軸索の分岐・伸長 の光操作を試みた。 その結果, 青色光を 30 分照射した細 胞には照射していないものに比べ, 軸索の分岐・伸長が 著しく促進されることが明らかになった（図4b)。この ことから, OaPACを用いることで神経細胞の構造形成を 光により制御することが可能であり, 神経疾患研究への 応用が期待される。

\section{5.おわりに}

光活性化アデニル酸シクラーゼ（PAC）はミドリムシ から発見され, 長年の間光反応機構と構造は不明であっ た。近年，シアノバクテリア由来のOscillatoriaから見出 されたOaPACについて大腸菌からの単離精製・結晶化· 構造解析に成功し, 世界で初めて構造に基づいて PAC の活性化機構を論じた. また, 光遺伝学の応用への道も 少し述べて来た。近年, 同じく植物プランクトン起源で あるチャネルロドプシンを利用することによる神経興 奮の光制御, いわゆる「光遺伝学, optogenetics」は急速 に普及した，OaPACを利用したcAMPを介する生体機能 光制御も概念上同類とみなされるものではあるが，はる かに広範で多彩な生命活動の光制御につながり，血管新 生・脳病変原生・神経回路ネットワーキング・記憶など の光発生医学現象の制御・解明・治療・創薬スクリーニ ングという広大な新分野の開拓を先導するものであり, かつ独創的な新領域の研究分野であると言える.今後, さまざまな光活性化タンパク質の創出とそれに基づく広 範で多彩な応用展開につながることが期待できる。

\section{謝 辞}

PFのBL-17A およびNW-12Aのスタッフの皆様のデー 夕測定の技術的なサポートにより構造決定まで至りまし た。この場をお借りしてお礼を申し上げます。また，東 邦大学薬学部薬品物理分析学教室の伊関峰生教授, 生 自治医科大学の柴山修哉教授, 浜松ホトニクス(株)中央研 究所の松永茂博士, 東京大学大学院薬学系研究科の小 山隆太准教授をはじめ多くの方にご支援やご指導を賜り ました。この場をお借りして厚くお礼申し上げます。

\section{文 献}

1) M. Iseki and T. Takahashi: in "Optogenetics", H. Yawo, H. Kandori and A. Koizumi, eds, pp.17-29, Springer Japan (2015).

2) M. Iseki, S. Matsunaga, A. Murakami, K. Ohno, K. Shiga, K. Yoshida, M. Sugai, T. Takahashi, T. Hori and M. Watanabe: Nature 415, 1047 (2002)

3) M. H. Ryu, O. V. Moskvin, J. Siltberg-Liberles and M. Gomelsky: J. Biol. Chem. 285, 41501 (2010).

4) M. Stierl, P. Stumpf, D. Udwari, R. Gueta, R. Hagedorn, A. Losi, W. Gärtner, L. Petereit, M. Efetova, M. Schwarzel, T. G. Oertner, G. Nagel and P. Hegemann: J. Biol. Chem. 286, 1181 (2011).

5) H. Yasukawa, A. Sato, A. Kita, K. Kodaira, M. Iseki, T. Takahashi, M. Shibusawa, M. Watanabe and K. Yagita: J. Gen. Appl. Microbiol. 59, 361 (2013).

6) M. Gomelsky and G. Klug: Trends Biochem Sci. 27, 497 (2002)

7) M. Ohki, K. Sugiyama, F. Kawai, H. Tanaka, Y. Nihei, S. Unzai, M. Takebe, S. Matsunaga, S. Adachi, N. Shibayama, Z. Zhou, R. Koyama, Y. Ikegaya, T. Takahashi, J. R. Tame, M. Iseki and S. Y. Park: Proc. Natl. Acad. Sci. U.S.A. 113, 6659 (2016).

8) S. Masuda and C. E. Bauer: Cell 110, 613 (2002).

9) S. Ito, A. Murakami, K. Sato, Y. Nishina, K. Shiga, T. Takahashi, S. Higashi, M. Iseki and M. Watanabe: Photochem. Photobiol. Sci. 4, 762 (2005)

10) S. Anderson, V. Dragnea, S. Masuda, J. Ybe, K. Moffat and C. Bauer: Biochemistry 44, 7998 (2005).

11) A. Kita, K. Okajima, Y. Morimoto, M. Ikeuchi and K. Miki: J. Mol. Biol. 349, 1 (2005).

12) C. Steegborn, T. N. Litvin, L. R. Levin, J. Buck and H. Wu: Nat. Struct. Mol. Biol. 12, 32 (2005).

13) K. Deisseeroth: Nat Methods. 8, 26 (2011).

14) H. J. Song and M. -m. Poo: Curr. Opinion Neurobiol. 9, 355 (1999).

15) Z. Zhou, K. F. Tanaka, S. Matsunaga, M. Iseki, M. Watanabe, N. Matsuki, Y. Ikegaya and R. Koyama: Sci. Rep. 5, 19679 (2016).

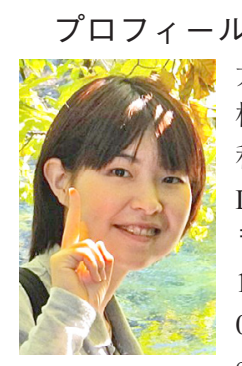

\section{大木規央 Mio OHKI}

横浜市立大学大学院生命医科学研究科構造創薬 科学研究室

Drug Design Laboratory, Yokohama City University 干 230-0045 横浜市鶴見区末広町 1-7-29

1-7-29 Suehiro, Tsurumi, Yokohama, Kanagawa 2300045, Japan

e-mail: mio-k67@tsurumi.yokohama-cu.ac.jp 最終学歴：横浜市立大学大学院国際総合科学研 究科博士課程 (2016年修了), 博士 (理学) 専門分野: 構造生物学・生物学 研究テーマ：センサータンパク質の構造生物学

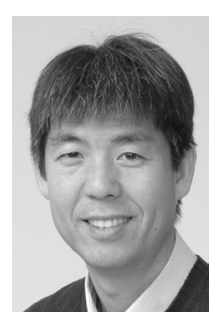

朴 三用 Sam-Yong PARK

横浜市立大学大学院生命医科学研究科構造創薬 科学研究室

Drug Design Laboratory, Yokohama City University 于 230-0045 横浜市鶴見区末広町 1-7-29

1-7-29 Suehiro, Tsurumi, Yokohama, Kanagawa 2300045, Japan

e-mail: park@tsurumi.yokohama-cu.ac.jp 最終学歴：大阪大学大学院基礎工学研究科博士 課程 (1995 年修了)

専門分野: 構造生物学·生化学

研究テーマ: 疾患由来タンパク質の構造生物学 